\title{
Kontribusi Program Pembinaan Calon Pengantin Terhadap Kesiapan Berumah Tangga Bagi Masyarakat Kota Malang
}

\author{
Ummu Najah, Ellyn Sugeng Desyanty, Edi Widianto \\ Fakultas Ilmu Pendidikan Universitas Negeri Malang \\ ummu.najah.170146@students.um.ac.id, ellyn.sugeng.fip@um.ac.id, \\ edi.widianto@fip.um.ac.id
}

\begin{abstract}
Received: 09 Juny 2021; Revised: 26 July 2021; Accepted: 28 August 2021
DOI: http://dx.doi.org/10.37905/aksara.7.3.1303-1312.2021
\end{abstract}

\begin{abstract}
This study aims to determine the prospective bride and groom development program, determine the household readiness of the prospective bride and groom coaching participants, and the contribution of the bride and groom coaching program to the readiness for marriage in KUA throughout Malang City. Respondents in this study were 88 participants of the bride and groom. The results of this study indicate that a) The Bridal Guidance Program is included in the good category, b) The household readiness of the bride and groom coaching participants is included in the good category, c) The contribution of the Bridal Guidance Program to Household Readiness is $70.04 \%$, meaning that there is a significant contribution. There is a big difference between the prospective bride and groom development program on household readiness.
\end{abstract}

Abstrak: Penelitian ini bertujuan untuk mengetahui program pembinaan calon pengantin, mengetahui kesiapan berumah tangga peserta pembinaan calon pengantin, dan kontribusi program pembinaan calon pengantin terhadap kesiapan berumah tangga di KUA Se-Kota Malang. Responden dalam penelitian ini sebanyak 88 peserta calon pengantin. Hasil penelitian ini menunjukkan bahwa a) Program pembinaan calon pengantin termasuk dalam kategori baik, b) Kesiapan berumah tangga peserta pembinaan calon pengantin termasuk dalam kategori baik, c) Kontribusi Program Pembinaan Calon Pengantin terhadap Kesiapan Berumah Tangga adalah 70,04\% artinya terdapat kontribusi yang besar antara program pembinaan calon pengantin terhadap kesiapan berumah tangga.

Kata Kunci: pembinaan, calon pengantin, kesiapan berumah tangga

\section{PENDAHULUAN}

Sarana yang sah dalam pembentukan keluarga berdasarkan ikatan agama adalah pernikahan. Pernikahan bukan hanya suatu cara terhormat untuk mendapatkan keturunan, menjaga faraj atau hanya menyalurkan naluri, atau hanya untuk menyalurkan biologis saja (Wahab dkk., 2017). Pernikahan yaitu penyatuan dua insan yang memiliki kepribadian yang berbeda dan disatukan untuk membangun rumah tangga dalam ikatan pernikahan untuk membentuk sebuah keluarga.

Terwujudnya keluarga yang sakinah mawaddah warohmah merupakan hal yang didambakan setiap keluarga, yaitu keluarga yang penuh cinta dan kasih sayang, harmonis, 
bahagia, dan keluarga yang damai. Kerja sama yang baik antar anggota keluarga diperlukan agar terwujudnta keluarga yang sakinah mawaddah warohmah dengan cara seluruh anggota keluarga dapat menjalankan peranya dengan baik. Kehidupan keluarga seperti sebuah bangunan, dan untuk melindunginya dari gempa bumi, guncangan, dan badai, harus dibangun di pondasi yang kuat dari bahan bangunan yang kokoh. Begitu pula dalam membangun sebuah keluarga atau rumah tangga dibutuhkan pondasi yang kuat yaitu ajaran agama Islam. Selain itu, kesiapan fisik, mental calon ayah maupun ibu, serta hak dan kewajiban suami istri perlu difahami setiap pasangan.

Berdasarkan laporan perkara yang diterima Pengadilan Agama Kota Madya Malang bulan Januari sampai dengan Februari 2021 terdata ada 156 cerai talak dan 427 cerai gugat, angka perceraian di Kota Malang tergolong tinggi. Oleh karena itu perlu diadakannya program pembinaan calon pengantin di Kota Malang yang merupakan salah satu kepeduliaan pemerintah terhadap pernikahan, sesuai dengan Peraturan Dirjen Bimas Islam Kemenag Nomor: DJ.II/542 Tahun 2013 diinstruksikan sebelum menikah setiap pasangan calon pengantin terlebih dulu harus diberikan pengetahuan atau pandangan mengenai makna suatu rumah tangga dengan mengikuti kursus calon pengantin (sucatin) yang diselenggarkan Kantor Urusan Agama (KUA). Pada peraturan berisi mengenai proses pelaksanaan kursus pranikah mulai dari petunjuk teknis dan pedoman untuk calon pengantin. Pedoman buku yang diberikan pada calon pengantin didalamnya berisi tentang gambaran atau kemungkinan yang terjadi dalam kehidupan berumah tangga, sehingga nantinya apabila terjadi masalah dalam berumah tangga dapat diminimalisir dan mengantisipasinya dengan baik.

Program pembinaan calon pengantin termasuk dari salah satu bagian Pendidikan Luar Sekolah karena dalam pelaksanaanya termasuk dalam kegiatan kursus karena peserta pembinaan calon pengantin mendapatkan bekal pengetahuan serta ketrampilan mengenai kehidupan berumah tangga atau berkeluarga dan dapat menambah kesiapan berumah tangga peserta pembinaan calon pengantin. Pernyataan tersebut sama dengan UU no 20 tahun 2003 tentang Sistem Pendidikan Nasional pasal 26 ayat (5) Tujuan dari kursus dan pelatihan adalah untuk mengembangkan potensi pribadi, mengembangkan karir, usaha dan kewirausahaan serta memberikan kecakapan hidup, ketrampilan, pengetahuan dan sikap yang diperlukan untuk pendidikan lebih lanjut di tingkat yang lebih tinggi di masyarakat. Menambah ketrampilan individu untuk mendukung fungsi dan tugas pada organisasi maupun untuk kehidupan individu itu sendiri merupakan tujuan pelatihan (Widianto, 2018)

Kantor Urusan Agama (KUA) sebagai tempat pelaksanaan pembinaan calon pengantin di Kota Malang memiliki 5 KUA yang ada di masing-masing kecamatan yaitu, KUA Blimbing, KUA Klojen, KUA Lowokwaru, KUA Sukun, dan KUA Kedungkandang. Pembinaan calon pengantin bertujuan untuk mengurangi angka perceraian yang ada dimasyarakat, mewujudkan keluarga yang harmonis dengan menambah pengetahuan dan pemahaman calon pengantin mengenai kehidupan rumah tangg, dan juga untuk menghindari kekerasan dalam rumah tangga (Amelia dkk., 2020).

Penelitian ini membahas tentang kontribusi program pembinaan calon pengantin terhadap kesiapan berumah tangga. Pelakasanaan program pembinaan calon pengantin memiliki kontribusi atau tidak terhadap kesiapan berumah tangga bagi masyarakat Kota Malang. Penelitian ini membahas tetang calon pengantin yang telah mengikuti program pembinaan calon pengantin dan kontribusinya terhadap kesiapan berumah tangga. 
Menurut (Sari dkk., 2016) dalam menentukan kesiapan menikah seorang individu ada delapan faktor utama yang dinilai penting, yaitu faktor ketrampilan, faktor ekonomi, faktor sosial, faktor emosi, faktor hubungan interpersonal, faktor kesiapan mental, faktor kesiapan fisik, faktor usia

Materi program pembinaan calon pengantin penyelenggaraanya sudah diatur pada Peraturan Dirjen Bimas Islam Kemenag tahun 2013. Pada peraturan tersebut, materi yang disampaikan dalam program pembinaan calon pengantin dibagi menjadi 3 kelompok, yaitu: kelompok dasar (perkenalan kebijakan pemerintah mengenai pembinaan pranikah), kelompok inti (pengenalan kehidupan rumah tangga), dan kelompok penunjang (pemantapan pemahaman pernikahan). Materi yang disampaikan mencakup tentang undang-undang KDRT, fungsi dalam keluarga, merawat cinta dalam keluarga dengan membangun komunikasi yang baik dalam keluarga, manajemen konflik dalam keluarga dengan memberikan cara agar anggota keluarga dapat menyelesaikan masalah tanpa emosi.

Kesiapan menikah yaitu keadaan seseorang yang sudah siap menerima tanggung jawab sebagai istri atau suami, sudah siap berhubungan fisik atau seskusal dengan pasangan, bersedia berhubungan dengan pasangan, telah siap membina keluarga, serta sudah siap mengurus anak (Duvall \& Miller, 1985). Ketika seseorang sudah memutuskan untuk menikah berarti sudah siap baik secara mental maupun psikisnya, sudah siap menjalankan peran sebagai suami atau istri, sudah siap membangun keluarga, sudah siap berhubungan secara fisik dengan pasangan, dan telah siap mengurus dan memiliki anak. Agar dapat mewujudkan keluarga yang harmonis dan bahagia, maka kesiapan menikah perlu disiapkan secara matang sebelum memasuki masa pernikahan.

Pernikahan bertujuan untuk membentuk keluarga yang bahagia serta merupakan bagian dari siklus kehidupan manusia (Syepriana dkk., 2018). Dalam membentuk keluarga yang bahagia dan harmonis banyak yang harus dipersiapkan sebelum memasuki jenjang pernikahan. Oleh karena itu, untuk mewujudkan pernikahan yang harmonis dan bahagia harus disiapkan dengan matang agar saat sudah memasuki usia pernikahan tidak kaget karena sudah mempersipkan sebelumya. Ada 6 upaya yang perlu dilakukan dalam persiapan pernikahan yaitu: keadaan kedua pasangan sebelum memasuki kehidupan berkeluarga, kesehatan jasmani maupun rohani kedua pasangan, pemahaman kedua pasangan mengenai pernikahan maupun keluarga, keadaan keluarga tempat dibesarkannya kedua pasangan, keadaan sosial maupun ekonomi keluarga, dan kehidupan beragama (Kenedi, 2005) .

Menurut (Sari dkk., 2016) dalam menentukan kesiapan menikah seorang individu ada delapan faktor utama yang dinilai penting, yaitu faktor ketrampilan, faktor ekonomi, faktor sosial, faktor emosi, faktor hubungan interpersonal, faktor kesiapan mental, faktor kesiapan fisik, faktor usia. Menurut (Blood, 1978) kesiapan menikah terdiri dari kesiapan emosi, peran, sosial, usia, dan finansial. Ada banyak persiapan yang harus disiapkan oleh calon pengantin serta banyak aspek yang harus diperhatikan atau dipertimbangkan agar ketika sudah waktunya menikah calon pengantin sudah siap dalam berumah tangga. Selain itu, kesiapan menikah dapat dilihat dari tujuh aspek yaitu aspek individu, emosi, intelektual, finansial, sosial, moral, dan mental istri (Syepriana dkk., 2018). Berdasarkan penelitian (Ghalili dkk., 2012) ada kesiapan menikah yang perlu dimiliki oleh calon pengantin antara lain: kesiapan interpersonal, mental, emosi, finansial, usia, moral, fisik, dan kontak sosial. 
Jadi dapat disimpulkan faktor- faktor kesiapan berumah tangga dapat dilihat dari 10 faktor,yaitu: kesiapan emosi, peran, sosial, usia, finansial, hubungan interpersonal, fisik, mental, intelektual, dan moral.

Penelitian ini membahas tentang kontribusi program pembinaan calon pengantin terhadap kesiapan berumah tangga. Pelakasanaan program pembinaan calon pengantin memiliki kontribusi atau tidak terhadap kesiapan berumah tangga bagi masyarakat Kota Malang. Penelitian ini meneliti calon pengantin yang telah mengikuti program pembinaan calon pengantin dan kontribusinya terhadap kesiapan calon pengantin dalam membangun rumah tangga. Penelitian ini bertujuan untuk mengetahui kontribusi program pembinaan calon pengantin terhadap kesiapan berumah tangga calon pengantin.

\section{METODE}

Metode penelitian kuantitatif yang digunakan pada penelitian ini menggunakan uji hipotesis regresi linier sederhana. Populasi dan sampel penelitian adalah peserta program pembinaan calon pengantin di KUA Se-Kota Malang. Peneliti menggunakan teknik Purposive Sampling untuk menemukan sampel dari subyek yang akan diteliti yaitu lembaga KUA di Kota Malang populasi dalam penelitian ini berjumlah 112 peserta pada bulan Maret 2021 dan sampel dalam penelitian ini berjumlah 88 peserta pembinaan calon pengantin yang ditentukan menggunakan rumus Slovin. Data program pembinaan calon pengantin diperoleh melalui kuesioner dengan menggunakan instrument materi yang disampaikan dalam program pembinaan calon pengantin yaitu kelompok dasar (perkenalan kebijakan pemerintah tentang pembinaan pranikah), kelompok inti (pengenalan kehidupan rumah tangga), dan kelompok penunjang (pemantapan pemahaman pernikahan). Data tentang kesiapan berumah tangga diperoleh melalui kuesioner dengan menggunakan faktor-faktor kesiapan berumah tangga dapat dilihat dari 10 faktor, yaitu: kesiapan emosi, peran, sosial, usia, finansial, hubungan interpersonal, fisik, mental, intelektual, dan moral.

Penelitian instrument ini menggunakan kuesioner dengan skala likert dengan 4 alternatif jawaban sebagai skala pengukuran datanya. Uji coba instrument penelitian ini dilakukan kepada 31 peserta pembinaan calon pengantin tahun 2020 dengan jumlah 60 pernyataan. Hasilnya ada 1 pernyataan yang tidak valid yang kemudian dilakukan tindakan drop out. Hasil uji realiabilitas pada variabel X dan Y nilai alpha Cronbach lebih dari 0,05 maka dapat disimpulkan bahwa instrument tersebut reliable. Teknik pengumpulan datanya menggunakan kuesioner dan dokumentasi. Kuesioner dibagikan langsung kepada peserta pembinaan calon pengantin di Kua setiap kecamatan Se-Kota Malang. Pelaksanaan penelitian dilaksanakan pada tanggal 15-24 Maret 2021. Analisis data pada penelitian ini menggunakan analisis statistik deskriptif, lalu uji asumsi klasik yaitu uji linieritas, uji normalitas, uji multikolineritas, dan uji heteroskedastitas. Pada tahap uji hipotesis menggunakan analisis regresi linier sederhana. 


\section{HASIL DAN PEMBAHASAN \\ Hasil}

Hasil penelitian pada program pembinaan calon pengantin diperoleh menggunakan kategori berdasarkan rumus (Azwar, 2012) yaitu sebagai berikut:

\begin{tabular}{llll}
\hline Rentang Nilai & F & \% & Keterangan \\
\hline $\mathrm{X}<85,11$ & 22 & 25 & Cukup Baik \\
\hline $85,11 \leq \mathrm{X}<103,91$ & 48 & 54,55 & Baik \\
\hline $\mathrm{X} \leq 103,91$ & 18 & 20,45 & Sangat Baik \\
\hline Jumlah & $\mathbf{8 8}$ & 100 & \\
\hline
\end{tabular}

Dari 88 peserta program pembinaan calon pengantin, sebanyak 48 jawaban peserta termasuk dalam kategori baik pada titik rentang 85,11 $\leq X<103,91$ (kategori baik) dan dipresentasikan menjadi 54,55\%. Pada hasil kesiapan berumah tangga diperoleh dengan menggunakan kategorisasi berdasarkan rumus Azwar yaitu sebagai berikut:

\begin{tabular}{lllc}
\hline Rentang Nilai & F & \% & Keterangan \\
\hline $\mathrm{X}<96,21$ & 17 & 19,32 & Cukup Baik \\
\hline $96,21 \leq \mathrm{X}<116,85$ & 52 & 59,09 & Baik \\
\hline $\mathrm{X} \leq 116,85$ & 19 & 21,59 & Sangat Baik \\
\hline Jumlah & $\mathbf{8 8}$ & 100 &
\end{tabular}

Dari keseluruhan responden sebanyak 88 peserta pembinaan calon pengantin, sebanyak 52 peserta termasuk dalam kategori baik dengan rentang nilai $96,21 \leq \mathrm{X}<$ 116,85 dan dipresentasikan menjadi 59,09\%.

Hasil uji linieritas menunjukkan nilai signifikansi $0,318>0,05$ maka dapat disimpulkan hubungan antara variabel bebas adalah linier. Hasil uji normalitas menunjukkan nilai signifikansi 0,618 > 0,05 maka dapat disimpulkan memenuhi syarat uji normalitas dan berdistribusi normal. Hasil uji multikolineritas menunjukkan nilai tolerance sebesar 1,000 > 0,10 dan nilai VIF 1,000 < 10 maka dapat disimpulkan tidak terjadi gejala multikolineritas. Hasil uji heteroskedastisitas menunjukkan nilai signifikasi 0,264 > 0,05 maka dapat disimpulkan tidak terjadi heteroskedastisitas.

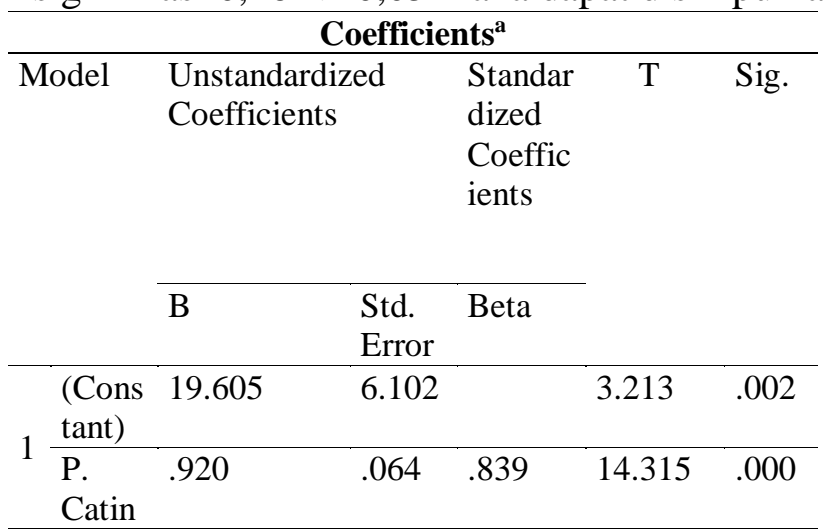

a. Dependent Variable: K. Rumah Tangga

$\mathrm{T}$ tabel $=\mathrm{t}(\mathrm{a} / 2: \mathrm{n}-\mathrm{k}-1)=\mathrm{t}(0,025: 86)=1.987934$

Berdasarkan tabel diatas diketahui bahwa t hitung 14,315 > t tabel 1,987 dan nilai signifikasi $0,000<0,05$ maka dapat disimpulkan Ha diterima sehingga secara parsial 
variabel program pembinaan calon pengantin $(\mathrm{X})$ berkontribusi secara signifikan terhadap kesiapan berumah tangga (Y).

Koefisien regresi tersebut bernilai positif, sehingga dapat dikatakan arah pengaruh variabel $\mathrm{X}$ dan $\mathrm{Y}$ positif. Hal ini menunjukkan semakin besar kontribusi program pembinaan calon pengantin semakin besar pula kesiapan berumah tangga peserta pembinaan calon pengantin.

\begin{tabular}{lcccr}
\hline \multicolumn{4}{c}{ Model Summary $^{\mathbf{b}}$} \\
\hline Model & $\mathrm{R}$ & $\begin{array}{c}\mathrm{R} \\
\text { Square }\end{array}$ & $\begin{array}{c}\text { Adjusted } \\
\mathrm{R} \\
\text { Square }\end{array}$ & $\begin{array}{c}\text { Std. } \\
\text { Error of } \\
\text { the } \\
\text { Estimate }\end{array}$ \\
\hline 1 & $.839^{\mathrm{a}}$ & 0.704 & 0.701 & 5.642 \\
\hline
\end{tabular}

a. Predictors: (Constant), Program Pembinaan

Calon Pengantin

b. Dependent Variable: Kesiapan Berumah

Tangga

Berdasarkan tabel diatas hasil dari uji analisis regresi linier sederhana koefisien determinasi sebesar 0,704 atau 70,4\%, Sehingga dapat disimpulkan variabel pengaruh program pembinaan calon pengantin $(\mathrm{X})$ terhadap variabel kesiapan berumah tangga $(\mathrm{Y})$ adalah sebesar $70,4 \%$.

\section{Pembahasan}

\section{Program Pembinaan Calon Pengantin}

Pedoman pelaksanaan kursus pra nikah yang terdapat pada peraturan Dirjen Bimas Islam pasal 2 No. DJ.II/542 tahun 2013 menyatakan bahwa peraturan ini bertujuan untuk meningakatkan pemahaman serta menambah pengetahuan kepada calon pengantin mengenai kehidupan berkeluarga atau berumah tangga untuk mewujudkan keluarga yang sakinah, mawaddah warahmah, memgurangi kekerasan dalam rumah tangga, mengurangi perceraian, serta perselisisihan dalam keluarga. Penyebab banyaknya konflik dalam keluarga adalah kurang matangnya persiapan mental dan fisik dari calon pengantin serta kurangnya pembekalan tentang pernikahan (Sundani, 2018). Oleh karena itu, diharapkan setelah adanya pembinaan calon pengantin masyarakat lebih mengetahui cara berumah tangga yang baik serta mengetahui hak dan kewajiban setiap pasangan dalam bekeluarga maupun dalam membina anggota keluarga agar dapat terwujudnya keluarga yang sakinah, mawaddah, dan warrahmah.

Berdasarkan data analisis deskripsi terdapat variabel program pembinaan calon pengantin yang telah dijelaskan sebelumnya, diperoleh bahwa program pembinaan calon pengantin di KUA Se-kota Malang dapat dikelompokkan menjadi tiga kategori yaitu untuk kategori yang cukup baik sebanyak 25\%, untuk kategori yang baik sebanyak $54,55 \%$, dan untuk kategori yag sangat baik sebanyak 20,45\%. Jadi, untuk program pembinaan calon pengantin termasuk kategori baik, dikarenakan pada kategori baik memiliki jumlah frekuensi yang paling banyak. Sedangkan kategorisasi nilai per sub variabel pada program pembinaan calon pengantin seluruh sub variabel termasuk dalam kategori baik, namun presentase paling tertinggi sebesar $73,86 \%$ pada sub variabel pengenalan kehidupan rumah tangga dan pemantapan pemahaman pernikahan. Sebagai 
upaya menambah kesiapn calon pengantin untuk membentuk keluarga yang bahagia dalam upaya mewujudkan kehidupan berkeluarga perlu mempersiapkannya dengan matang, dengan pembinaan pranikah (Alam, 2019). Pemahaman proses keluarga lebih difokuskan oleh konselor keluarga (Mubasyaroh, 2017) dalam pemantapan pemahaman pernikahan. Semua materi yang disampaikan pada program pembinaan calon pengantin telah menambah pribadi individu dalam berkeluarga serta menambah kesiapan berumah tangga para peserta calon pengantin. Hal yang sangat penting dalam mencapai kesuksesan keluarga adalah dengan mempersiapkan kesiapan menikah dengan baik sebelum menikah (Afni, 2020).

\section{Kesiapan Berumah Tangga Pesera Pembinaan Calon Pengantin}

Kesediaan seseorang untuk membentuk suatu ikatan batin maupun lahir antara pasangan suami istri untuk membentuk keluarga yang sah serta diakui menurut agama, masyarakat, dan hukum disebut kesiapan menikah (Dewi, 2006). Kesiapan menikah dapat terbentuk ketika sesorang memliki pengetahuan dan persepsi yang positif mengenai pernikahan. Persepsi positif terhadap pernikahan akan terbentuk apabila seseorang memiliki pengetahuan yang baik tentang pernikahan. Ketika seseorang sudah memutuskan untuk menikah berarti sudah siap baik secara mental maupun psikisnya, sudah siap menjalankan peran sebagai suami atau istri, sudah siap membangun keluarga, sudah siap melakukan hubungan seksual, serta sudah siap memiliki anak dan mengasuh atau mendidik anak. Kesejahteraan dalam pernikahan dapat tercapai apabila kedua pasangan yang akan menikah memiliki kesiapan menikah (Mawarpuri dkk., 2019). Kesipan menikah pelu disiapkan dengan matang sebelum memasuki jenjang pernikahan agar dapat mewujudkan keluarga yang bahagia dan harmonis.

Berdasarkan data anlisis deskripsi variabel kesiapan berumah tangga dapat diketahui kesiapan berumah tangga peserta pembinaan calon pengantin di KUA Se-kota Malang terdapat tiga kategori yaitu untuk kategori cukup baik dengan hasil presentase sebanyak $19,32 \%$, untuk kategori baik dengan hasil presentase sebanyak 59,09\%, dan untuk kategori sangat baik dengan hasil presentase sebanyak 21,59\%. Jadi, dapat disimpulkan bahwa variabel kesiapan berumah tangga termasuk pada kategori baik dengan hasil presentase sebesar 59,09\% yang disebabkan karena memiliki jumlah frekeunsi yang paling banyak. Meminimalisisr terjadinya ketidakstabilan dalam keluarga serta mengurangi risiko terjadinya perceraian apabila kedua pasangan memilki kesiapan menikah yang baik (Tsania dkk., 2015).

\section{Kontribusi Program Pembinaan Calon Pengantin Terhadap Kesiapan Berumah Tangga}

Riset ini memiliki tujuan untuk menguji hipotesis penelitian yang berbunyi "terdapat kontribusi program pembinaan calon pengantin terhadap kesiapan berumah tangga". Hasil informasi analisis penelitian menggunakan bantuan Spss versi 21 for windows. Setelah peneliti melakukan analisis deskripsi kemudian peneliti melakukan uji asumsi klasik yang pertama adalah uji linearitas, berdasarkan hasil pengujian linearitas dapat diketahui bahwa nilai signifikan 0,318 yang berarti nilai sig $>0,05$ maka dapat disimpulkan bahwa variabel bebas yaitu program pembinaan calon pengantin (X) dengan variabel terikat kesiapan berumah tangga (Y) mempunyai hubungan linier. Uji yang 
kedua yaitu uji normalitas diperoleh nilai Kolmogorov-Smirnov $Z$ pada nilai unstandardized residual untuk variabel bebas yaitu program pembinaan calon pengantin terhadap variabel terikat yaitu kesiapan berumah tangga sebesar 0,618 diperoleh dari nilai Asymp.Sig.(2-tailed), sehingga kesimpulannya bahwa nilai Sig lebih besar dari 0,05 maka variabel mempunyai distribusi yang normal. Uji yang ketiga yaitu uji multikolinearitas diketahui pada variabel program pembinaan calon pengantin bahwa nilai VIF $1,000<10$ dan nilai tolerance sebesar $1,000>0,10$ maka dapat diambil kesimpulan variabel program pembinaan calon pengantin (X) tidak terjadi gejala multikolinearitas. Uji yang keempat yaitu uji heteroskedastisitas menggunakan uji glejser nilai signifiks diketahui pada variabel program pembinaan calon pengantin memiliki nilai $0,264>0,05$, sehingga kesimpulanya tidak terjadi heteroskedastisitas.

Berdasarkan analisis regresi linier sederhana diperoleh model persamaan $\mathrm{Y}^{\prime}=$ $19,605+0,920 X$ yang artinya konstanta sebesar 19.605 menunjukkan jika program pembinaan calon pengantin (X) bernilai nol (0), maka kesiapan berumah tangga (Y) bernilai 19,605. Koefisien regresi $X$ sebesar 0,920 menunjukkan setiap bertambah 1\% nilai program pembinaan calon pengantin, maka nilai kesiapan berumah tangga akan bertambah sebesar 0,920. Pengaruh variabel X terhadap Y adalah positif karena koefisien regresi tersebut bernilai positif artinya semakin tinggi pengaruh program pembinaan calon pengantin maka semakin meningkat kesiapan berumah tangga peserta calon pengantin. Berdarakan uji parsial (uji t) diketahui $\mathrm{t}$ hitung 14,315>t tabel 1,987 dan nilai signifikasi $0,000<0,05)$ artinya $\mathrm{t}$ hitung bernilai positif maka kontribusi program pembinaan calon pengantin berpengaruh positif terhadap kesiapan berumah tangga dan nilai signifikasi bernilai $0,000<0,05$ maka ada pengaruh yang signifikan. Nilai sebesar 0,704 atau 70,4\% adalah nilai koefisien determinasi $\left(R^{2}\right)$ maka dapat diambil kesimpulan bahwa pengaruh atau kontribusi program pembinaan calon pengantin $(X)$ terhadap variabel kesiapan berumah tangga (Y) adalah sebesar 70,4\%. Sedangkan 29,6\% kesiapan berumah tangga dipengaruhi variabel lain yang tidak ada dalam penelitian ini. Sehingga kesimpulannya bahwa Ha diterima karena ada pengaruh signifikan dan positif antara program pembinaaan calon pengantin $(\mathrm{X})$ terhadap kesiapan berumah tangga $(\mathrm{Y})$.

\section{PENUTUP}

\section{Kesimpulan}

Program pembinaan calon pengantin termasuk pada kategori baik dengan jumlah frekuensi sebesar 48 dan dipresentasikan menjadi 54,55\%. Pada kesiapan berumah tangga termasuk pada kategori baik dengan jumlah frekuensi sebesar 52 dan dipresentasikan menjadi 59,09\%. Nilai Signifikasi pada uji regresi menunjukkan hasil nilai signifikasi $0,000<$ 0,05, maka dapat disimpulkan memiliki pengaruh yang signifikan. Nilai sebesar 0,704 atau $70,4 \%$ adalah nilai koefisien determinasi $\left(R^{2}\right)$, sehingga dapat disimpulkan bahawa pengaruh program pembinaan calon pengantin $(X)$ terhadap variabel kesiapan berumah tangga (Y) adalah sebesar 70,4\% artinya terdapat kontribusi yang besar antara program pembinaan calon pengantin terhadap kesiapan berumah tangga

\section{Saran}

Bagi KUA Kota Malang diharapkan pemerintah melaksanakan program pembinaan calon pengantin secara rutin agar semua masyarakat Kota Malang yang akan menikah mempunyai kesempatan mengikuti pembinaan calon pengantin. Bagi peserta pembinaan 
calon pengantin diharapkan menerapkan semua yang diajarkan pada saat pembinaan dalam kehidupan rumah tangga agar dapat terwujudnya keluarga yang sakinah, mawaddah, dan warahmah. Bagi peneliti selanjutnya hasil penelitian ini dapat dijadikan tambahan rujukan dari hasil penelitian ini untuk dikembangkan oleh peneliti selanjutnya, bisa menggunakan variabel lainnya agar teridentifikasi faktor lain yang bepengaruh dalam kesiapan berumah tangga.

\section{DAFTAR RUJUKAN}

Afni, Safura. 2020. "Layanan Konseling Islami Dalam Membina Kesiapan Menikah Pada Siswa Smk Broadcasting Bina Creative Medan." Jurnal Ikatan Alumni Bimbingan dan Konseling Islam (IKA BKI) 2(2):1-129.

Alam, Samsul. 2019. "Pembinaan Pranikah Dalam Peningkatan Pemahaman Keagamaan Calon Pengantin Di Kua Kecamatan Sleman.” 4(1):25-30.

Azwar, S. 2012. Metode Penelitian. Yogyakarta: Pustaka Pelajar.

Amelia, N., D. I. Efendi, \& L. A. Marfuah. 2020. "Layanan Bimbingan Pranikah dalam Meningkatkan Keharmonisan Keluarga di KUA Cileunyi." Irsyad: Jurnal Bimbingan ... 8:41-58. doi: 10.15575/irsyad.v8i1.1480.

Blood, M, D. 1978. Marriage 3(rd). New York: Free Pass.

Dewi, Ika Sari. 2006. Kesiapan Menikah Pada Wanita Dewasa Awal Yang Bekerja. Skripsi tidak diterbitkan. Medan: Universitas Sumatera Utara.

Duvall, E, M., \& C. Miller, B. 1985. Marriage and Family Development. New York, US: Harper and Row.

Ghalili, Zohreh, Ozra Etemadi, S. Ahmad Ahmadi, Maryam Fatehizadeh, \& Mohammad Reza Abedi. 2012. "Marriage readiness criteria among young adults of Isfahan: a qualitative study." International Journal of Contemporary Research in Business 4(4):1076-83.

Kementerian Agama. 2013. Peraturan Direktur Jendral Bimbingan Masyarakat Islam. Nomor:DJ.II/542 Tahun 2013 Tentang Pedoman Penyelenggaraan Kursus Pra Nikah (online),(https://jatim.kemenag.go.id/file/file/peraturantentangPNS/esdz142587374 4.pdf), diakses 9 April 2020.

Kenedi, H, Gusril. 2005. Model Konseling Pranikah Berorientasi Pengembangan Konsep-DirI : Studi Kasus Tentang Persiapan Pernikahan Mahasiswa Etnis Minangkabau di IAIN Imam Bonjol Padang. Tesis tidak diterbitkan. Bandung: Universitas Pendidikan Indonesia.

Mawarpuri, Marty, Syarifah Faradina, Sari Mawaddah, \& Lely Safrina. 2019. "Perbedaan Kesiapan Menikah Pada

Dewasa Awal Ditinjau Dari Jenis Kelamin Di Banda Aceh.” Empati 8(1):320-28.

Mubasyaroh. 2017. "Konseling Pra Nikah Dalam Mewujudkan Keluarga Bahagia (Studi Pendekatan Humanistik Carl R. Rogers).” KONSELING RELIGI Jurnal Bimbingan Konseling Islam 7(2):1. doi: 10.21043/kr.v7i2.2128.

Pengadilan Agama Kota Kodya Malang Tentang Laporan Perkara yang Diterima Pengadilan Agama Kota Madya Malang bulan Januari sampai dengan Februari 2021 (online), (https://www.pamalangkota.go.id/arsip/images/Laporan/Perkara_Diterima/perkara _diterima_per_februari_2021.jpg), dikases 19 Juli 2021. 
Sari, Yunita, Andhita Nurul Khasanah, \& Sarah Sartika. 2016. "Studi Mengenai Kesiapan Menikah Pada Muslim Dewasa Muda." Prosiding Seminar Nasional Penelitian dan PKM Kesehatan 6(1):2010-14.

Sundani, Fithri Laela. 2018. "Layanan Bimbingan Pra Nikah dalam Membentuk Kesiapan Mental Calon Pengantin.” Irsyad : Jurnal Bimbingan, Penyuluhan, Konseling dan Psikoterapi Islam 6(2):165-84.

Syepriana, Yunita, Firdaus Wahyudi, \& Ari Budi Himawan. 2018. "Gambaran karakteristik kesiapan menikah dan fungsi keluarga pada ibu hamil usia muda." Jurnal Kedokteran Diponegoro 7(2):935-46.

Tsania, Nurlita, Euis Sunarti, \& D. K. Pranaji. 2015. "Karakteristik Keluarga, Kesiapan Menikah Istri, dan Perkembangan Anak Usia 3-5 tahun." Jurnal Ilmu Keluarga dan Konsumen 8(1):28-37. doi: 10.24156/jikk.2015.8.1.28.

Undang-Undang RI No.20 SIDIKNAS Tahun 2003 tentang Sistem Pendidikan Nasional. (online), http://pendis.kemenag.go.id/file/dokumen/uuno20th2003ttgsisdiknas.pdf., dikakses 19 Juni 2021.

Wahab, Zulkfli, Supardin, \& Patimah. 2017. "Bimbingan Keluarga Sakinah.” Jurnal Diskursus Islam 05:146-60.

Widianto, Edi. 2018. "Pola Penyelenggaraan Pendidikan dan Pelatihan Di Balai Diklat Keuangan Kota Malang." Ilmu Pendidikan: Jurnal Kajian Teori dan Praktik Kependidikan 3(1):40-49. doi: 10.17977/um027v3i12018p040. 